Fundamentals of Operating Systems 


\section{Macmillan Computer Science Series}

Consulting Editor

Professor F. H. Sumner, University of Manchester

S. T. Allworth, Introduction to Real-time Software Design

Ian O. Angell, A Practical Introduction to Computer Graphics

G. M. Birtwistle, Discrete Event Modelling on Simula

T. B. Boffey, Graph Theory in Operations Research

Richard Bornat, Understanding and Writing Compilers

J. K. Buckle, The ICL 2900 Series

J. K. Buckle, Software Configuration Management

Robert Cole, Computer Communications

Derek Coleman, A Structured Programming Approach to Data*

Andrew J. T. Colin, Fundamentals of Computer Science

Andrew J. T. Colin, Programming and Problem-solving in Algol 68*

S. M. Deen, Fundamentals of Data Base Systems*

J. B. Gosling, Design of Arithmetic Units for Digital Computers

David Hopkin and Barbara Moss, Automata*

Roger Hutty, Fortran for Students

Roger Hutty, Z80 Assembly Language Programming for Students

H. Kopetz, Software Reliability

Graham Lee, From Hardware to Software: an introduction to computers

A. M. Lister, Fundamentals of Operating Systems, second edition*

G. P. McKeown and V. J. Rayward-Smith, Mathematics for

Computing

Brian Meek, Fortran, PL/I and the Algols

Derrick Morris and Roland N. Ibbett, The MU5 Computer System

John Race, Case Studies in Systems Analysis

B. S. Walker, Understanding Microprocessors

Peter J. L. Wallis, Portable Programming

I. R. Wilson and A. M. Addyman, A Practical Introduction to Pascal 


\title{
Fundamentals of Operating Systems
}

\author{
A. M. Lister, M.A.
}

\author{
University of Queensland
}

\section{Second Edition}

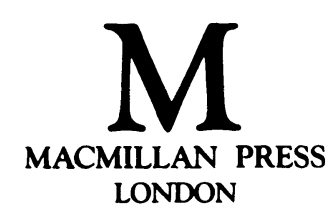


(C) A. M. Lister, 1975,1979

All rights reserved. No part of this publication may be reproduced or transmitted, in any form or by any means, without permission.

First edition 1975

Reprinted 1977, 1978

Second edition 1979

Reprinted 1980 (twice), 1981 (four times), 1982, 1983 (three times)

\author{
Published by \\ THE MACMILLAN PRESS LTD \\ London and Basingstoke \\ Companies and representatives \\ throughout the world \\ Typeset in Times Press Roman by \\ Styleset Limited, Salisbury, Wilts.
}

\title{
British Library Cataloguing in Publication Data
}

Lister, Andrew Martin

Fundamentals of operating systems. -

2nd ed.

1. Operating systems (Computers)

I. Title

001.6'425 QA76.6

ISBN 978-0-333-27287-9 ISBN 978-1-349-16134-8 (eBook)

DOI 10.1007/978-1-349-16134-8 


\section{to my parents}




\section{Contents}

Preface $\quad$ xi

1 Introduction 1

1.1 Real-time systems 2

1.2 Job-shop systems

1.3 The 'paper' operating system 4

2 Functions and Characteristics of an Operating System 6

2.1 Operating system functions 6

2.2 Operating system characteristics 9

$\begin{array}{lr}2.3 \text { Desirable features } & 10\end{array}$

3 Concurrent Processes 12

3.1 Programs, processes, and processors 12

3.2 Communication between processes $\quad 14$

3.3 Semaphores 16

3.4 Summary $\quad 23$

4 The System Nucleus 25

4.1 Essential hardware facilities 25

4.2 Outline of the nucleus $\quad 27$

4.3 Representation of processes 28

4.4 The first-level interrupt handler $\quad 29$

4.5 The dispatcher 32

4.6 Implementation of wait and signal 35

5 Memory Management 40

5.1 Objectives $\quad 40$

5.2 Virtual memory $\quad 42$

5.3 Implementation of virtual memory 43

5.4 Memory allocation policies $\quad 52$ 
$\begin{array}{ll}5.5 \text { The working set model } & 58\end{array}$

$\begin{array}{ll}5.6 \text { Implementation in the paper system } & 60\end{array}$

6 Input and Output $\quad 61$

6.1 Design objectives and implications $\quad 62$

$\begin{array}{ll}6.2 \text { The I/O procedures } & 64\end{array}$

$\begin{array}{ll}6.3 \text { The device handlers } & 67\end{array}$

6.4 Buffering $\quad 69$

$\begin{array}{ll}6.5 \text { File devices } & 70\end{array}$

$\begin{array}{ll}6.6 \text { Spooling } & 72\end{array}$

6.7 Conclusion $\quad 74$

7 The Filing System $\quad 75$

$\begin{array}{ll}7.1 \text { Objectives } & 75\end{array}$

$\begin{array}{ll}7.2 \text { File directories and file storage } & 76\end{array}$

$\begin{array}{ll}7.3 \text { Sharing and security } & 81\end{array}$

$\begin{array}{ll}7.4 \text { Secondary memory organisation } & 84\end{array}$

$\begin{array}{ll}7.5 \text { File system integrity } & 85\end{array}$

$\begin{array}{ll}7.6 \text { Opening and closing files } & 86\end{array}$

$\begin{array}{lr}7.7 \text { Conclusion } & 90\end{array}$

8 Resource Allocation and Scheduling $\quad 91$

8.1 General observations $\quad 91$

$\begin{array}{ll}8.2 \text { Allocation mechanisms } & 92\end{array}$

$\begin{array}{ll}8.3 \text { Deadlock } & 94\end{array}$

$\begin{array}{lr}8.4 \text { The scheduler } & 99\end{array}$

$\begin{array}{ll}8.5 \text { Scheduling algorithms } & 102\end{array}$

$\begin{array}{ll}8.6 \text { Process hierarchies } & 106\end{array}$

$\begin{array}{ll}8.7 \text { Control and accounting } & 109\end{array}$

$\begin{array}{ll}8.8 \text { Summary } & 113\end{array}$

9 Protection $\quad 114$

$\begin{array}{ll}\text { 9.1 Motivation } & 114\end{array}$

9.2 Development of protection mechanisms $\quad 115$

$\begin{array}{ll}9.3 \text { A hierarchical protection system } & 118\end{array}$

$\begin{array}{ll}9.4 \text { General systems } & 120\end{array}$

$\begin{array}{ll}9.5 \text { Conclusion } & 125\end{array}$

10 Reliability 126

$\begin{array}{ll}10.1 \text { Objectives and terminology } & 126\end{array}$

$\begin{array}{ll}10.2 \text { Fault avoidance } & 128\end{array}$

$\begin{array}{ll}10.3 \text { Error detection } & 131\end{array}$ 
10.4 Fault treatment

10.6 Multilevel error handling

10.7 Conclusion

11 Job Control

11.1 Some general remarks

11.2 Command languages

140

11.3 Job control languages

140

11.4 The job pool

145

11.5 System messages

146

11.6 Passage of a job through the system 147

Conclusion

148

References

152

Index 


\section{Preface}

An operating system is probably the most important part of the body of software which goes with any modern computer system. Its importance is reflected in the large amount of manpower usually invested in its construction, and in the mystique by which it is often surrounded. To the non-expert the design and construction of operating systems has often appeared an activity impenetrable to those who do not practise it. I hope this book will go some way toward dispelling the mystique, and encourage a greater general understanding of the principles on which operating systems are constructed.

The material in the book is based on a course of lectures I have given for the past few years to undergraduate students of computer science. The book is therefore a suitable introduction to operating systems for students who have a basic grounding in computer science, or for people who have worked with computers for some time. Ideally the reader should have a knowledge of programming and be familiar with general machine architecture, common data structures such as lists and trees, and the functions of system software such as compilers, loaders, and editors. It will also be helpful if he has had some experience of using a large operating system, seeing it, as it were, from the outside.

The first two chapters of the book define the functions of an operating system and describe some common operating system characteristics. Chapter 3 establishes the process as a basic concept in the discussion of the concurrent activities which go on inside an operating system, and describes how processes communicate with each other. The rest of the book then describes the construction of an operating system from the bottom up, starting at the interface with the machine hardware and ending at the interface with the user. By the end of the book the system which has been constructed is seen to possess the features demanded at the beginning.

Throughout the book I have tried to show how each stage in the construction of an operating system naturally follows on the previous ones, and have emphasised the logical structure of the system as a whole. I have done this for two reasons. The first is pedagogical: my experience indicates that students gain a better understanding of complex material if it is presented in a coherent manner. The second is frankly polemic: this is the way I believe operating systems should be built. Attention to structure and logical dependence are the 
best means we have of building operating systems which are easy to understand, easy to maintain, and relatively error free.

Finally, I would like to thank the many friends and colleagues who have helped in the writing of this book. In particular I would like to thank David Lyons, who has been a fertile source of ideas and comment; and David Howarth, who made valuable comments on an earlier draft. Thanks are also due to Colin Strutt, Morris Sloman, John Forecast, Ron Bushell and Bill Hart, who have made constructive suggestions for improving the text.

ANDREW LISTER

\section{Preface to the Second Edition}

Any book on computer science suffers from the fact that its subject matter is undergoing rapid change, both technological and conceptual. A book on operating systems is no exception: the hardware on which systems run is being revolutionised by the large scale integration of components, and ideas about what operating systems should do are being modified by changing user requirements and expectations. Although this book is about 'fundamentals', which can be expected to be less volatile than other topics, it would be foolish to ignore the developments which have occurred in the four years since publication.

Consequently I have amended the text in three main ways for this edition. First, there is an additional chapter on reliability, a topic whose importance has increased dramatically as reliance on computer systems has grown in many areas of life. Secondly, the references to real-life operating systems have been updated to include systems which have come into use since the first edition, and references to the literature have been similarly updated. Thirdly, I have altered the presentation of certain topics so as better to reflect current ideas, and have expanded the conclusion to indicate what developments can be expected in the future.

Other changes in the text have been motivated by feedback from readers of the first edition. Here I owe a great debt to my students, who have had the perception to point out errors, and the good sense to expose inadequate exposition. Any improvements in this respect are due largely to them, though any remaining inadequacies are, of course, my own. 